\title{
IMPLEMENTASI BUKU AJAR DALAM PENELITIAN TINDAKAN KELAS: EFEKTIVITAS BUKU AJAR MIKROBIOLOGI PADA PERKULIAHAN
}

\section{Implementation Of Textbook In Class Action Research: Effectiveness Of Microbiological Textbook in Lectures}

\author{
Fitri Wijarini $^{\mathrm{a}}$ \\ a Jurusan Pendiidkan Biologi/Universitas Borneo Tarkan, Kota Tarakan, Kalimantan Utara, Indonesia \\ ${ }^{*}$ Corresponding author: Jl. Amal Lama, Tarakan Timur, Tarakan, Kalimantan Utara, 77123, Indonesia. E-mail: fitriwijarini2@gmail.com
}

\begin{abstract}
Abstrak
Penelitian ini bertujuan untuk mengetahui efektivitas buku ajar mikrobiologi sebagai sumber belajar mahasiswa Pendidikan Biologi Universitas Borneo Tarakan. Penelitian ini merupakan penelitian tindakan kelas dengan jumlah subyek penelitian sebanyak 33 mahasiswa. Subyek penelitian dalam penelitian ini adalah mahasiswa semester 5B Jurusan Pendidikan Biologi Universitas Borneo Tarakan. Instrument yang digunakan dalam penelitian ini berupa tes hasil belajar. Analisis data dilakukan secara deskriptif kuantitatif dengan Teknik presentase. Hasil penelitian menunjukkan bahwa penggunaan buku ajar mikrobiologi dapat meningkatkan hasil belajar mahasiswa. Ketuntasan bealajar pada siklus satu sebesar $38.33 \%$ sedangkan ketuntasan pada siklus dua sebesar $95.66 \%$. Sehingga dapat disimpulkan bahwa penggunaan buku ajar mikrobiologi sebagai sumber belajar efektif untuk meningkatkan hasil belajar mahasiswa.
\end{abstract}

Kata kunci: Efektivitas, buku ajar, mikrobiologi

\begin{abstract}
This study aims to determine the effectiveness of microbiology textbooks as a learning resource for Biology Education students at the University of Borneo Tarakan. This research is a classroom action research with 33 students as research subjects. The research subjects in this study were 5B semester students of the Department of Biology Education, University of Borneo Tarakan. The instrument used in this study was a learning outcome test. Data analysis was carried out by descriptive quantitative with percentage technique. The results showed that the use of microbiology textbooks could improve student learning outcomes. The completeness of learning in the first cycle was $38.33 \%$, while the second cycle's completeness was $95.66 \%$. So, it can be concluded that the use of microbiology textbooks as a learning resource effectively improves student learning outcomes.
\end{abstract}

Keywords: Effectiveness, textbooks, microbiology 


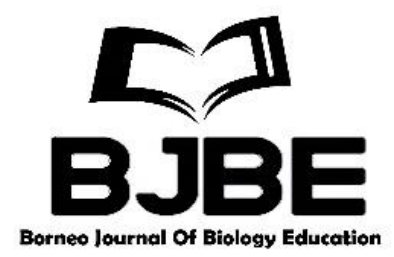

Vol. 3 No. 1, 2021; pp. $42-47$

P-ISSN: 2715-6826 (print); E-ISSN: 2714-6073 (online)

Received: 16/02/2021

Revised: 03/03/2021

Accepted: 18/03/2021

\section{Pendahuluan}

Ketersedian sumber belajar dan bahan ajar dalam sebuah proses pembelajaran sangat penting bagi guru dan siswa, bagi dosen dan mahasiswa. Keberadaan bahan ajar memudahkan dosen untuk mencapai tujuan pembelajaran. Menurut Sanjaya (2008), bahan ajar merupakan bagian dari kurikulum yang harus dikuasai oleh peserta didik untuk mencapai standar kompetensi pada mata pelajaran berdasarkan kompetensai dasar di satuan pendidikan tertentu. Sedangkan menurut Ginting (2008) menjelaskan bahwa bahan pembelajaran merupakan rangkuman materi berupa cetak atau tersimpan dalam bentuk file baik berupa verbal ataupu tertulis yang diberikan ke siswa. Aisyah (2020) menjelasakan bahwa terdapat 3 fungsi utama bahan ajar dalam proses penyelenggaraan pembelajaran, yakni sebagai pedoman guru, pedoman bagi peserta didik, serta sebagai alat evaluasi dalam pencapaian hasil pembelajaran. Bagi guru ketersediaan bahan ajar memberikan gambaran dan arahan kompetensi apa yang harus dikuasai oleh peserta didik. Bagi siswa ketersediaan bahan ajar memberikan gambaran dan arahan terkait aktivitas apa saja yang harus dilakukan untuk mencapai kompetensi yang harus dicapai. Bahan ajar yang dapat digunakan sebagai penunjang proses pembelajaran dapat berupa modul, hand out, buku refernsi ataupun buku ajar.

Buku ajar meruakan buku yang ditulis oleh ahli pada bidang tertentu, sesuai dengan kaidah tertentu yang kemudian digunakan untuk proses pembelajaran. Buku ajar yang dikembangkan sendiri oleh guru/ dosen pada mata pelajaran/ mata kuliah tertentu dinilai lebih unggul dibandingkan keberadaan buku ajar yang sudah ada. Keberadaan bukua ajar penting dalam proses pembelajaran, terlebih jika belum adanya ketersedianan buku ajar. Maka penting bagi guru/ dosen untukmengembangkan sendiri buku ajar apad mata pelajaran/ mata kuliah tertentu. Kelebihan yang diperoleh ketika guru/ dosen mengembangkan buku ajar sendiri adalah: a). muatan materi dapat disesuaikan antara kebutuhan belajr siswa dan tuntutan kurikulum, b). dapat menyediakan sendiri buku ajar sesuai kebutuhan, c). menambah wawasan pengetahuan guru/dosen dalam mengembangkan materi pelajaran karena dalam penyusunan buku ajar memerlukan berbagai referensi, d). buku ajar yang dikembangkan sendiri oleh guru/ dosen lebih mudah dipahami oleh peserta didik karena buku ajar dikembangkan menggunakan bahasa guru ketika menjelaskan di depan kelas. Dengan demikian dapatmemudahkan guru untuk membangun komunikasi efektif antara guru/ dosen dengan peserta didik.

Tujuan dalam penelitian ini adalah untuk mengetahui efektivitas buku ajar mikrobiologi yang telah dikembangkan oleh dosen pengampu sehingga nantinya dapat dimanfaatkan sebagai sumber belajar oleh mahasiswa jurusan Pendidikan Biologi di Universitas Borneo Tarakan. Menurut Slavin (1994) dalam Saputri (2016) bahwa kefektivan menekankan pada kemampuan pengajar dalam mengelola pembelajaran serta sejauh mana proses pembelajaran dapat menciptakan kemandirian peserta didik dalam belajar. Berdasarkan hal tersebut untuk melihat efektivitas penggunaan bahan ajar yang telah dikembangkan dilnilai berdasarkan: 1). Kemandirian belajar mahasiswa, 2). Aktivitas mahasiswa saat perkuliahan, 3). Kemampuan pengajar dalam mengelola kelas, 4) adanya peningkatan kemampuan mahasiswa dalam memecahkan masalah, 5). Respon mahasiswa terhadap bukua ajar yang telah dikembangkan. Namun dalam penelitian ini efektivitas dibatasi pada kemampuan memecahkan masalah melalui soal yang telah dibuat oleh peneliti. 


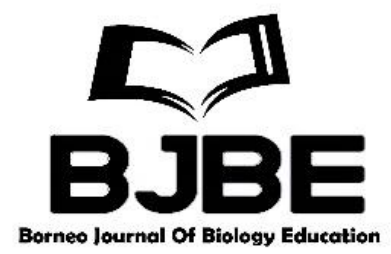

Vol. 3 No. 1, 2021; pp. $42-47$

P-ISSN: 2715-6826 (print); E-ISSN: 2714-6073 (online)

Received: 16/02/2021

Revised: 03/03/2021

Accepted: 18/03/2021

\section{Material dan metode}

Penelitian ini merupakan jenis Penelitian Tindakan Kelas. Penelitian PTK dipilih karena peneliti hanya mengampu 1 kelas untuk matakuliah mikrobiologi umum. Subyek penelitian ini adalah mahasiswa semester 6 yang sedang megambil mata kuliah mikrobiologi umum. Subyek penelitian sebanyak 66 mahasiswa. Penelitian dilakukan di FKIP jurusan Pendidikan Biologi Universitas Borneo Tarakan di semester 5 tahun ajaran 2020/2021. Siklus penelitian PTK ini terdiri dari 2 siklus, dimana setiap siklus dilakukan sebanyak 2 pertemuan, dan setiap siklus teridri atas empat tahapan yang meliputi tahap perencanaan, pelaksanaan, observasi, dan refleksi. Buku ajar yang digunakan dalam penelitian ini telah dilakukan validasi oleh ahli dan juga telah dilakukan uji kepraktisan (Wijarini, 2020; Wijarini, 2021).

Penelitian ini tersusun dati tahapan berikut:

a. Tahap perencanaan, pada tahap ini peneliti menyusun perangkat pembelajaran mikrobiologi umummulai dari SAP, instrument penelitian berupa soal hasil belajar yang telah disesuaikan dengan indicator pembelajaran serta lembar pengamatan (observasi). Penilaian yang dilakukan hanya untuk mengukur kemampuan kognitif mahasiswa. Indicator keberhasilan pembelajaran adalah ketika mahasiswa telah mendapatkan nilai minimal 70 atau dengan kategori.

b. Tahap pelaksanaan, peneliti melakukan proses pengajaran dengan menggunakan buku ajar mikrobiologi umum yang telah dibuat dan telah divalidasi oleh validator ahli.

c. Tahap observasi, Tahap ini dilakukan dengan mengamati jalannya proses pembelajaran. Observasi difokuskan pada aktivitas mahasiswa selama proses pembelajaran. Sehingga pada tahap ini butuh observer yang mengamati dan mencatat aktivitas mahasiswa selama pembelajaran.

d. Tahap Refleksi, peneliti menganalisis data hasil belajar kognitif (tes) mahasiswa dan menganalisis lembar observasi yang telah diisi. Tujuan dari menganalisis adalah untuk menemukan adanya permasalahan yang terjadi selama proses pembelajaran sehingga dapat dijadikan evaluasi apkah proses penelitian dapat dilanjutkan atau bahkan diberhentikan. Instrument pengambilan data berupa tes hasil belajar berupa soal pilihan ganda dan tertulis.indikator ketuntasan belajar adalah jika mahaiswa mendapatkan nilai minimal sebanyak 70 atau dengan kriteria $\mathrm{B}$.

\section{Hasil dan Diskusi}

Penelitian tentang efektivitas buku ajar mikrobiologi dilakukan dalam 2 (dua) siklus. Masing-masing siklus terdiri dari 2 kali pertemuan. Penilaian terhadap hasil belajar dilakukan pada setiap akhir siklus. Hasil belajar mahasiswa disajikan pada Table 1.

Tabel 1. Hasil Belajar Mahasiswa Terhadap Penggunaan Buku Ajar Mikrobiologi

\begin{tabular}{ccc}
\hline Siklus & Tuntas & Tidak Tuntas \\
\hline 1 & $38.33 \%$ & $61.77 \%$ \\
\hline 2 & $95.66 \%$ & $4.44 \%$ \\
\hline
\end{tabular}

Berdasarkan tabel 1. Terlihat bahwa ketuntasan pada siklus 1 tergolong masih rendah yaitu sebanyak $38.33 \%$ sedangkan yang tidak tuntas srbanyak $61.77 \%$. Pada siklus 2 terdapat peningkatan ketuntasan hasil belajar mahaiswa menjadi $95.66 \%$, sedangkan yang tidak tuntas mengalami penurunan sebesar $4.44 \%$. 

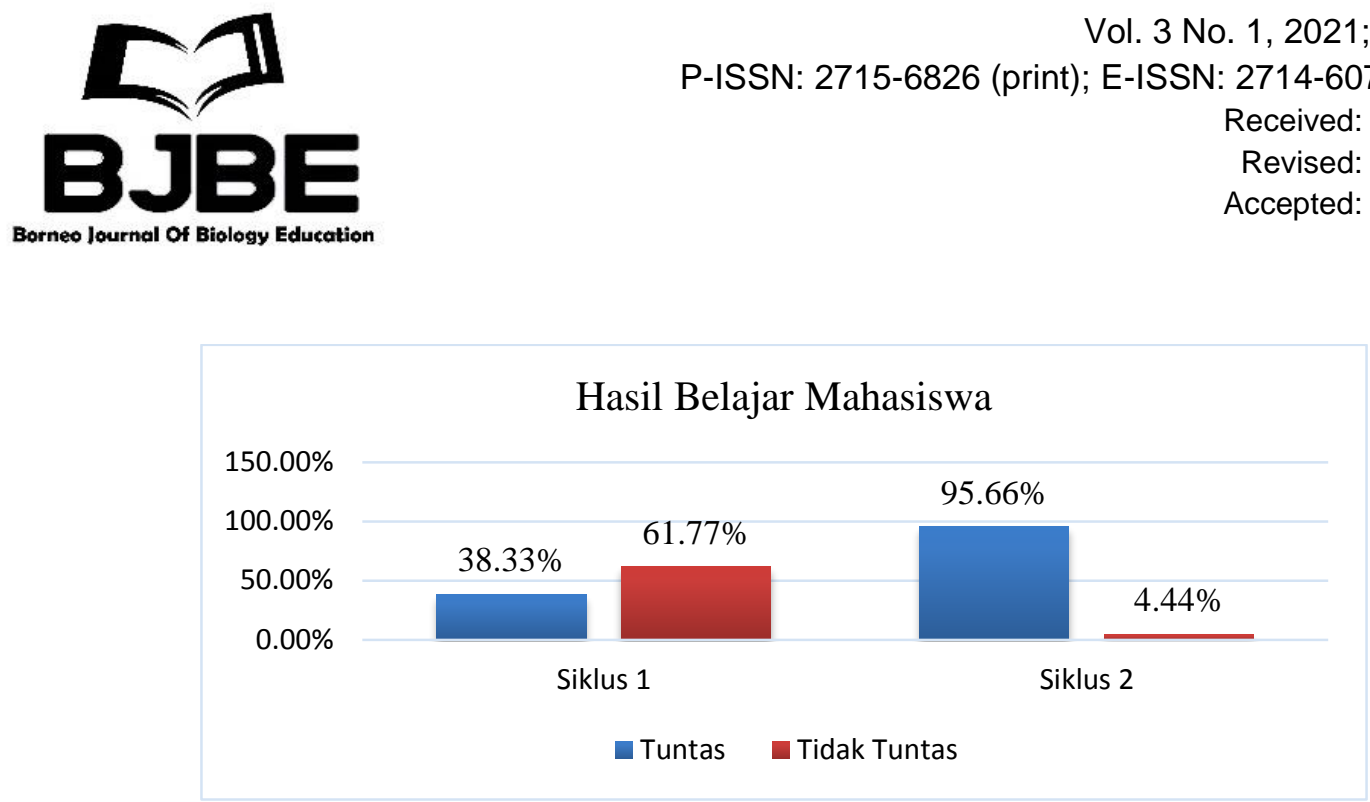

Gambar 1. Gambar diagram hasil belajar mahasiswa

Siklus satu diperoleh ketuntasan hanya sebesar $38.83 \%$ sedangkan yang tidak tuntas sebesar $61.77 \%$. Berdasarkan hasil penelitian ketidaktuntasan pada siklus satu karena banyak materi yang tidak disertai gambar serta banyak yang menggunakan istilah-istilah asing yang belum diketahui oleh mahasiswa. Sebagaimana muatan materi perrkuliahan mikrobiologi, hampir sebagian besar kajian materi mikrobiologi bersifat abstrak dan mikroskopis. Contoh materi yang dipelajari pada matakuliah ini misalnya bakteri, reproduksi bakteri, mekanisnme pertahanan inang dalam tubuh, virus, penyakit yang disebabkan oleh bakteri ataupun virus, dan lain-lain. Materi mikrobiologi bersifat abstrak. Begitu juga dengan istilah asing dalam matakuliah mikrobiologi. Hal ini cukup menjadi kendala manakala mahasiswa tidak paham dengan makna istilah asing yang ada. Sehingga kesulitan dalam mencerna dan memahami makna yang ada. Maka dari itu pada pertemuan selanjutnya penyampaian materi disajikan dengan menampilkan lebih banyak gambar pada materi-materi yang bersifat abstrak serta mengenalkan istilah-istilah asing yang sering ada pada matakuliah mikrobiologi melalui buku ajar mikrobiologi yang telah dibuat oleh peneliti yang juga mengampu matakuliah tersebut.

Siklus dua presentase ketuntasan hasil belajar mahasiswa meningkat menjadi $95.66 \%$. Hal ini disebabkan mahasiswa lebih mudah memahami konsep-konsep materi mikrobiologi melalui buku ajar yang dikembangkan. Adanya gambar yang merupakan visualisasi dari materi yang bersifat abstrak serta pengenalan istilah asing merupakan karakteristik dari buku ajar yang dikembangkan oleh peneliti. Sanaky (2009) dan Abrori et al. (2016) menjelaskan bahwa salah satu bahan ajar berbasis gambar adalah bersifat konkrit dan bersifat lebih nyata. Sholihah (2019) menambahkan bahwa gambar merupakan salah satu alat bantu visual yang dapat digunakan untuk mengenalkan, serta memperjelas konsep yang bersifat abstrak. Bahan ajar berupa teks yang disertai gambar memudahkan mahasiswa dalam memahami materi, karena teks dapat membantu memperjelas deskripsi dari gambar. Hal ini didukung oleh Putri (2017) yang menyebutkan bahwa penggnaan bahan ajar berbasis gambar dalam pembelajran lebih efektif dibandingkan dengan menggunakan bahan ajar biasa (tidak disertai gambar). Pengalaman belajar dalam proses pembelajaran di perguruan tinggi sangat penting. Tidak hanya sekedar memberikan konsep-konsep penting. Salah satu cara yang dapat dilakukan dalam memberikan pengalaman belajar adalah dengan penggunaan bahan ajar yang dapat mengembangkan kemampuan berfikir kreatif (Hartati, 2019). Ilmia (2018) menyatakan bahwa keberadaan buku ajar sangat penting dalam kegiatan pembelajaran namun perlu perancangan bahan ajar dengan memasukkan sejumlah prinsip agar mahasiswa dapat menguasi dan meningkatkan kompetensi sesuai tuntuan kurikulum. 


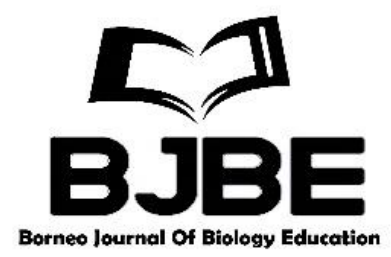

Vol. 3 No. 1, 2021; pp. $42-47$

P-ISSN: 2715-6826 (print); E-ISSN: 2714-6073 (online)

Received: 16/02/2021

Revised: 03/03/2021

Accepted: 18/03/2021

\section{Kesimpulan}

Berdasarkan hasil penelitian disimpulkan bahwa penggunaan buku ajar mikrobiologi sebagai sumber belajar mahasiswa Pendidikan Biologi efektif dapat meningkatkan hasil belajar mahasiswa. Peningkatan hasil belajar mahasiswa terlihat pada meningkatnya presentase ketuntasan mahasiswa pada siklus 2 menjadi $95.66 \%$. Hasil juga menunjukkan bahwa penggunakan buku ajar akan sangat mempengaruhi hasil belajar mahasiswa dalam sebuah perkuliahan. Buku ajar yang sesuai dengan karakter mahasiswa tentunya akan membawa dampak yang positif bagi mahasiswa.

Penelitian lanjutan tentunya bisa dilaksanakan untuk melihat sejauh mana efektifitas buku ajar yang telah dikembangkan jika diterapkan di Institusi lainnya. Selain itu, penelitian untuk pengaruh buku ajar bisa dilaksanakan dengan menggunakan kuasi eksperimen untuk melihat perbandingan kelompok yang menggunakan buku ajar mikrobiologi dan yang tid menggunakan.

\section{Daftar Pustaka}

Abrori, F. M., Yulida, R., Adhani, A., Wijarini, F., \& Nugroho, E. D. (2016). Media Pembelajaran Biologi. Yogyakarta: Genom.

Aisyah, S., Evih N.,\& Triyanto. 2020. Bahan Ajar Sebagai Bagian dalam Kajian Problematika Pembelajaran Bahasa Indonesia. Jurnal Salaka. 2(1). No. 61-65.

Hartati, E., Sundaryono, A., \& Sipriyadi, S. (2019). Pengembangan Audio Visual Bahan Ajar Mikrobiologi Berbasis Penelitian Bakteri Lipolitik Untuk Mengukur Kemampuan Berpikir Kreatif. PENDIPA Journal of Science Education, 3(1), 14-19. Ilmia, Silfi \& Fitri W. (2018). Efektifitas Buku Ajar Pendidikan Lingkungan Hidup Berbasis Potensi Lokal Tarakan. Jurnal Pedagogia Hayati 2(1): 33-36.

Indriati, R. (2013). Identifikasi Penggunaan Bahan Ajar Pada Mata Pelajaran Ekonomi Materi Akuntansi Kelas XI IPS Di SMA Negeri 1 Taman. Jurnal Pendidikan Akuntansi (JPAK), 1(3).

Putri, IW. (2017). Pengembangan Bahan Ajar IPS Berbasis Gambar Kelas III Sekolah Dasar. http://repository.upy.ac.id/1556/1Artikel.pdf. Diakses 17 Januari 2021.

Sanaky, HAH. (2009). Media Pembelajaran. Yogyakarta: Safrina Insania Press.

Saputri, D. F., Fadilah, S., \& Wahyudi, W. (2016). Efektivitas Penggunaan Buku Ajar Fisika Matematika Berbasis Inkuiri dalam Perkuliahan Fisika Matematika. Jurnal Penelitian \& Pengembangan Pendidikan Fisika, 2(2), 7-14.

Sholihah, M. A., \& Sofiyana, M. S. (2019). Analisis Kebutuhan Bahan Ajar Mikrobiologi Untuk Mahasiswa Program Studi Pendidikan Biologi. Bioma: Jurnal Biologi dan Pembelajaran Biologi, 4(2), 123-132.

Slavin, R., (1994). Educational Psycologi. Boston: Allyn and Bacon Publishing Company. 


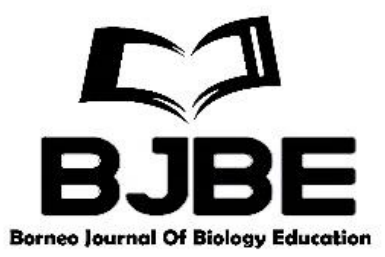

Vol. 3 No. 1, 2021; pp. 42-47

P-ISSN: 2715-6826 (print); E-ISSN: 2714-6073 (online)

Received: $16 / 02 / 2021$

Revised: 03/03/2021

Accepted: 18/03/2021

Wijarini, F. (2020). Pengembangan Buku Ajar Mikrobiologi Sebagai Sumber Belajar Mata Kuliah Mikrobiologi Umum Untuk Mahasiswa Jurusan Pendidikan Biologi Universitas Borneo Tarakan. Biopedagogia, 2(2), 130-137.

Wijarini, F. (2021). Kepraktisan Buku Ajar Mikrobiologi Umum: Kajian Ujicoba Pengembangan. Biopedagogia, 3(1), 37-42. 